\title{
TERANG IMAN DAN KEBENARAN \\ DI ERA REVOLUSI INDUSTRI 4.0
}

\author{
Kanisius Catur Christian dan Kevin Hendrarto T
}

STFT Widya Sasana Malang

\begin{abstract}
Abstrak
Fokus dari tulisan ini ialah menyadarkan manusia di era revolusi industri 4.0 akan adanya kebenaran-kebenaran semu dengan terang-terang palsunya yang menjerat manusia agar berpaling dari Sang Kebenaran sejati. Lewat algoritma, oleh para pemilik kepentingan, konsep manusia diubah dan hanya dipersoalkan soal mahluk badaniah belaka. Lewat kebenaran-kebenaran semu, manusia dijadikan alat pembaruan data yang tentu menguntungkan para pemilik kepentingan. Metode dari penelitian paper ini ialah studi kepustakaan, dimana penulis membaca dan mempelajari dari berbagai sumber buku untuk membahas topik. Dari analisis paper ini, manusia di era revolusi industri 4.0 disadarkan untuk mencari kebenaran sejati lewat tuntunanterang iman, sebuah Terang yang tidak akan meredup dan bercahaya lebih kuat dibandingkan terang-terang semu.
\end{abstract}

Kata Kunci: Kebenaran Sejati, Kebenaran Semu, Terang iman, Era revolusi industri 4.0

\begin{abstract}
The focus of this paper is to realize that people in the era of industrial revolution 4.0 will have false truths with false truths that ensnare people to turn away from the true Truth.Through algorithms, by the owners of interests, human concept is changed and only questioned about mere body creatures. Through false truths, human beings are used as data update tools that certainly benefit the owners of interests. The method of this paper's research is the study of literature, where the author offers from various sources of books to discuss topics. From the analysis of this paper, people in the era of industrial revolution 4.0 was made aware to look for the true Truth through the guidance of Faith, a light that will not dim and glow more strongly in the light of false light.
\end{abstract}

Keywords: Truth and Pseudo Truth, The Light of Faith, The Era of industrial Revolution 4.0

\section{Pendahuluan}

Manusia di era revolusi industri 4.0 menemukan banyak sekali kebenaran- 
kebenaran semu yang mengaburkan pandangan mereka akan Kebenaran yang sejati. Kebenaran semu ini memunculkan terang-terang yang memikat hati manusia untuk terjerumus kedalamnya. Setelah terang ini meredup, manusia akan menjadi kehilangan harapan, arah, dan tujuan hidupnya karena terang palsu itu muncul dan menjerumuskan manusia kedalam kebenaran semu. Kebenaran-kebenaran semu di era revolusi industri 4.0 ini muncul dari pemilik kepentingan yang meraup keuntungan dari manusia-manusia lewat pemrograman algoritma konsep manusia. Manusia hanyalah menjadi alat pembaruan data, dan menjadi mesin teknologi itu. Eksistensi akan kehadirannya di dunia dikaburkan, bagi para pemilik kepentingan manusia hanyalah soal badaniah semata. Lantas, bagimana manusia dapat menuju Sang Kebenaran Sejati tanpa terjerumus kedalam kebenaran semua lewat terang-terang palsu yang dipancarkannya?

\section{Apa itu Kebenaran}

Kehidupan manusia kerap dihadapkan pada persoalan tentang kebenaran. Pencarian akan kebenaran itu dilakukan oleh manusia untuk menjelaskan keadaan yang cocok dan yang sesungguhnya atas apa yang dilakukan dan diketahuinya. Berdasarkan pengalaman akan adanya kebenaran dalam kehidupan manusia, maka beberapa ahli mencoba mencari pengertian yang sesungguhnya atas apa arti kebenaran itu.

a. Georg Wilhem Friedrich Hegel,kebenaran itu bukan sesuatu yang stabil, yang menunjuk pada realitas sebagai demikian. Kebenaran ialah sesuatu yang tumbuh, berkembang, hidup, berubah-ubah (bukan dalam arti bertentangan satu sama lain tetapi menyusun bentuk-bentuk kebenaran yang lebih tinggi). ${ }^{1}$ Artinya kebenaran itu bersifat dinamis dan mendapat pengertiannya dari waktu ke waktu. Namun melalui pengalamannya, lama kelamaan manusia pada akhirnya akan sampai pada penemuan akan kebenaran yang sesungguhnya atau lebih tinggi.

b. Plato, kebenaran berarti itu yang selaras dengan realitas.

c. Menurut Albertus Agung, ada 4 definisi kebenaran. Pertama, benar ialah itu yang ada. Kedua, kebenaran ialah itu yang menampilkan ada sesuatu. Ketiga, kebenaran adalah suatu pembenaran yang dapat dipersepsi melulu akal budi. Keempat, kebenaran sebagai ketidak-terpisahannya ada dan itu yang ada. ${ }^{2}$

Secara umum, para ahli menyebut pencarian akan kebenaran yang sesungguhnya adalah aktivitas dari akal budi yang dimiliki oleh manusia, yakni mampu memperoleh pengertian dan pemahaman akan berbagai hal termasuk juga persoalan kebenaran. Manusia juga dapat sampai pada

1 Armada Riyanto, "Metafisika” (Diktat, STFT Widya Sasana, 2002), 46.

2 Ibid., 46. 
pemahaman akan kebenaran karena kebenaran selalu bersinggungan atau menunjuk pada realitas. Melalui pemahaman yang dimiliki ini, maka kebenaran tersebut dapat digolongkan ke dalam beberapa karakteristik berdasarkan hubungannya dengan realitas. Pertama, kebenaran sensibilis, yang merupakan kerja pertama proses memproduksi pengetahuan dalam akal budi manusia sehingga realitas dapat diketahui dan dipahami. Kedua, kebenaran logis yang memampukan manusia untuk mampu menjelaskan realitas dan yang ketiga adalah kebenaran etis yang memampukan manusia untuk menghidupi realitas itu, dimanifestasikan, diwujudkan secara nyata dan dihayati. Karakteristik dan pengelompokan kebenaran-kebanaran yang dihidupi oleh manusia ini memberi gambaran bahwa manusia itu sebenarnya mampu sampai pada pemahaman akan kebenaran itu sendiri namun tidak menutup kemungkinan pula bahwa manusia itu salah dalam menilai kebenaran. Sebab seperti yang telah dipersoalkan sebelumnya bahwa antara manusia yang satu dengan yang lain memiliki kebenaran yang berbeda-beda di dalam dirinya sendiri.

Kebenaran adalah kebenaran sejauh merupakan itu realitas yang bisa kita kenali/yang bisa kita pikirkan/yang bisa kita jelaskan dan bisa kita hidupi. ${ }^{3}$ Namun bagaimana dengan Allah. Manusia dengan akal budinya pun mampu memikirkan tentang Allah, bisa mengenalinya dan bisa dipikirkan. Akan tetapi, hal ini tidak mengindikasikan bahwa manusia dengan akal budinya mampu mengenali Allah secara sempurna. Allah adalah sang Kebenaran itu sendiri, Ia mengatasi realitas. Allah adalah Sang Kebenaran yang dari-Nya segala apa yang ada mengalir dan ambil bagian daripada-Nya. Manusia tidak mampu mencapai pemahaman yang sebenarnya akan Allah tersebut. Thomas Aquinas mengatakan bahwa puncak pencarian manusia adalah menyatukan diri pada sang Kebenaran sejati yaitu Allah. Menyatukan diri mengindikasikan pula bahwa manusia akan selalu memiliki keterarahan pada Allah atau keterarahan pada kebenaran itu sendiri.

Pada akhirnya, kebenaran merupakan aspek ada sejauh ada artinya kebenaran merupakan aspek langsung dari segala apa yang ada. Manusia sejauh ada mengungkapkan kebenaran sekaligus dalam dinamika cara adanya mengejar dan berupaya menggenggam, menghidupi, dan menyatukan diri dengan Sang Kebenaran itu sendiri. Manusia sejauh ada selalu dalam pencarian/pengembaraan menuju kebenarannya. ${ }^{4}$ Proses pencarian dan pengembaraan merupakan proses yang berlangsung secara terus menerus. Ketika suatu kebenaran sebelumnya tidak lagi relevan di saat yang sekarang, maka manusia akan mencari apa kebenaran yang relevan akan di kehidupan yang sekarang ini.

3 Ibid., 47.

4 Armada Riyanto, “Diktat Metafisika” (Diktat, STFT Widya Sasana, 2002), 49. 


\section{Terang Iman dan Kebenaran}

Iman selalu berkaitan dengan kepercayaan yang dimiliki oleh seseorang akan sesuatu hal. Berdasarkan arti katanya, iman adalah kepercayaan (yang berkenaan dengan agama); keyakinan dari kepercayaan kepada Allah, nabi, kitab dan sebagainya. ${ }^{5}$ Untuk mempertanggungjawabkan iman dan kepercayaan yang dimiliki oleh seseorang, manusia kerap menuntut sebuah kebenaran dari apa yang diimaninya. Kebenaran akan iman yang dihidupi oleh seseorang akan bertahan jika orang tersebut mampu memberikan sebuah kebenaran atas apa yang diimaninya. Maka praktis pengetahuan akan kebenaran menjadi sesuatu yang pokok dalam iman agar seseorang dapat sampai pada terang atau keadaan yang sesungguhnya. Dalam hal ini, kita membutuhkan pengertian, sebab tanpa itu semua kita tidak dapat berdiri teguh, kita tidak dapat bergerak maju. Iman tanpa kebenaran tidak dapat menyelamatkan, tidak dapat memberi pijakan kaki yang pasti. ${ }^{6}$

Manusia selain menanggap bahwa kebenaran satu-satunya adalah kebenaran teknologi yakni, kebenaran adalah sesuatu yang kita hasilkan dalam membangun dan mengukur dengan keterampilan ilmiah, kebenaran adalah apa yang berjalan dan apa yang menjadikan hidup lebih mudah serta lebih menyenangkan. ${ }^{7}$ Ketika manusia mampu menciptakan kemudahan dan kebahagiaan melalui apa yang dilakukannya itulah yang disebut sebagai kebenaran. Kemudahan dan kebahagiaan itu kemudian tercipta melalui adanya teknologi yang merupakan hasil karya manusia. Juga mengakui adanya kebenaran subjektif. Kebenaran subjektif artinya kebenaran itu lahir dari tiap-tiap orang, yang mencakup keyakinan-keyakinannya yang terdalam namun kebenaran-kebenaran tersebut hanya berlaku benar bagi orang tersebut dan tidak dapat diajukan kepada yang lain sebagai suatu upaya untuk melayani kebaikan bersama. ${ }^{8}$

Kedua kebenaran yang telah dijelaskan di atas tentu mengindikasikan bahwa kedua kebenaran itu lahir dari usaha manusia atau keyakinan manusia itu sendiri. Di antara kedua kebenaran yang dihasilkan manusia ini tentu ada kebenaran yang menjadi sumber dari semua kebenaran yang dipercayai oleh manusia. Kebenaran itu sendiri adalah kebenaran yang dapat secara menyeluruh menjelaskan kehidupan manusia sebagai individu dan dalam masyarakat namun sering dipandang dengan rasa curiga. ${ }^{9}$ Rasa curiga menunjukkan bahwa manusia zaman sekarang ini kurang meyakini adanya Kebenaran yang seperti itu. Kebenaran yang sesungguhnya itu sudah tidak

5 https://kbbi.web.id/iman, diakses tanggal 18 Desember 2020.

6 Fransiskus, Ensiklik Lumen Fidei Terang Iman, Penterj. R.P. T. Krispurwana Cahyadi (Jakarta: Dokpen KWI, 2014), art. 24.

7 Lumen Fidei, art. 25.

8 Ibid.

9 Ibid. 
lagi relevan atau tidak lagi dipercayai. Manusia dituntut untuk memiliki pengetahuan akan kebenaran yang sesungguhnya untuk mampu tetap berdiri pada pijakan yang kokoh.

Pengetahuan dan pemahaman akan Kebenaran yakni kebenaran yang dapat secara menyeluruh menjelaskan kehidupan kita sebagai individu dalam masyarakat pada akhirnya akan berkaitan pula dengan iman. Kebenaran ini akan mendapat tempat dalam terang iman itu sendiri. Untuk mendapat pengetahuan akan kebenaran dalam kaitannya dengan iman maka perlu pula untuk mengetahui apa saja pengetahuan yang terdapat dalam iman. Dalam teks suci dikatakan bahwa hati adalah inti dari pribadi manusia yang mencakup semua dimensi yang berbeda namun saling terkait satu sama lain seperti tubuh dan roh, ruang batin dan keterbukaan pada dunia dan pada sesama dan jika hati dapat menjaga dimensi-dimensi itu maka saat itu pula manusia menjadi terbuka pada kebenaran dan kasih. ${ }^{10}$ Kasih itu sendiri adalah cara relasional dalam memandang dunia, yang kemudian menjadi suatu bentuk pengetahuan yang dibagikan, suatu pandangan melalui mata sesama dan padangan yang dibagikan atas semua yang ada. ${ }^{11}$ Cara yang relasional dalam memandang dunia tentu mengandung suatu kebenaran di dalamnya sehingga mampu dibagikan kepada setiap manusia pada umumnya. Kasih dan kebenaran memiliki satu kesatuan dengan kebenaran. Kasih yang terikat pada kebenaran pada akhirnya akan membawa individu pada suatu terang atau pemahaman baru.

Karena kebenaran itu lahir dari kasih, dia dapat meresap ke dalam hati, ke dalam inti pribadi setiap orang. Maka, jelaslah bahwa iman bukanlah suatu yang keras dan kaku, melainkan suatu yang tumbuh dalam kebersamaan penuh hormat dengan yang lain. Seorang yang percaya bukanlah orang yang angkuh, sebaliknya kebenaran menuntunnya pada kerendahan hati, sebab kita, kaum beriman, mengetahui bahwa, alih-alih kita sendiri memiliki kebenaran, kebenaranlah yang memeluk dan memiliki kita. Juga terang iman, yang berpadu dengan kebenaran kasih tidaklah berada di luar dunia material, sebab kasih senantiasa hidup dalam tubuh dan roh. ${ }^{12}$

\section{Kebenaran di Era Revolusi Industri 4.0}

Revolusi yang terjadi dalam industri mengubah mindset manusia pula. Kebenaran dalam media sosial misalnya, tidak lagi terkait dengan faktanya melainkan telah bergeser kepada perkara "siapa" yang menyebarkan dan "apa" yang diviralkan. Bagi peserta didik, pembelajar yang benar untuk zaman ini ialah menjadi "followers". Kerja tidak lagi identik dengan kodrat kehadiran manusia, melainkan telah bergeser sejalan dengan usaha otomatisasi.

10 Lumen Fidei, art. 26.

11 Ibid., art. 27.

12 Ibid., art. 34 . 
Bisnis yang dulunya konvensional telah dirobek menjadi bisnis online. Tindakan bersama-sama seperti duduk bersama, minum bersama, dengan waktu yang bersama telah menjadi penghalang bagi era ini. Kecemasan akan prosedur pengamanan dan privasi bukan hanya "dimana"-nya mudah diketahui, bahkan "apa yang dilakukan".

Kemajuan teknologi juga memperkokoh konektivitas. Namun apakah dari sendirinya kemajuan itu "menyatukan" manusia-manusia? Fragmentasifragmentasi adalah jawabannya. Fenomena perpecahan, ketidakstabilan hidup bersama, dan perjalanan hidup dan masa depan yang tidak nyaman dan damai malah didapatkan.

Identitas seseorang turut mengalami perkembangan. Jika ingin diketahui siapakah seseorang itu, maka penjelasannya meliatkan pula media sosial. Identitasku dengan kata lain "berada di" akun sosial mediaku. Oleh karenanya setiap orang berlomba-lomba untuk melakukan pembaharuan status. Identitasnya perlu ada perbaikan seiring perkembangan.

Dalam hal komunitas, diadopsi sebuah "gramatika" baru. Cara kerja gramatika ini ialah mengumpulkan, tetapi di lain pihak juga menyingkirkan. Dengan kata lain jika orang ingin "survive" di kelompok tertentu mereka mengadopsi sebutan-sebutan yang merendahkan dan menyingkirkan orang lain (meninggikan dan memuliakan kehadiran kelompoknya).

Etika telah berada di "pinggiran" etika itu sendiri. Manusia tidak lagi mampu berkata dan bahkan meyakini mana yang baik dan mana yang buruk. Ini juga dipengaruhi oleh masuknya manusia ke sebuah ruangan virtual yang sangat luas, tetapi nyatanya didorong ke "bilik" yang sempit. Inilah algoritma yang telah dirancang untuk memformat manusia menjadi seperti para pemiliki kepentingan inginkan. Sugesti yang ditanamkan layaknya sebuah echo-chamber effect. Manusia diyakinkan untuk percaya dan memilih mana yang benar menurut pemiliki kepentingan.

Relasi antar manusia dalam era ini cenderung tidak mendalam atau malahan sama sekali tidak mendalam. Contohnyataialahtawarkanskemalike or dislikesebagairelasibarudarisosial media. Jika manusia tidak menyukai yang lain, dengan mudahnya ia akan memutuskan hubungan.

Being manusia pada jaman ini tidak lagi mementingkan menata hidup masa depan. Waktu hanya bergulir begitu saja. "Momen"-ku adalah hal yang lebih penting dimana "aku" hanya menjalaninya dan busy dengan segala notifikasi yang masuk di device-ku. Dia bukan hanya kehilangan kepedulian terhadap "ada bersama" (being with) orang lain, tetapi juga tidak "melibatkan" dirinya dengan masa depannya.

Gagasan manusia di Era 4.0 berciri materialistis, antara lain: ${ }^{13}$

13 Bdk., Valentinus. “Antara EUREKA dan ERICA: Konsep Manusia di Era 4.0," Seri Filsafat Teologi29,no. 28 (Oktober 2019): 64-73. 
1) Keyakinan umum manusia sebagai individu subyek yang utuh dan integral, memiliki esensi dan kesadaran diri dilawan dengan afirmasi bahwa organisme adalah algoritma, dan manusia tidaklah individual, tetapi dividual. Manusia merupakan kumpulan dari banyak algoritma yang berbeda-beda dan tidak memiliki suara batin tunggal atau kedirian.

2) Keyakinan akan DIRI yang otentik dan secara penuh bebas disangkal dengan menunjukkan bahwa algoritma yang membentuk manusia tidaklah bebas. Mereka dibentuk oleh gen dan tekanan lingkungan, dan mengambil keputusan baik secara deterministik atau acak. Semua aktivitas dan pikiran manusia sudah tertentu karena faktor genetik dan akibat dari penyesuaian diri dengan berbagai macam faktor yang berada di luar dirinya.

3) Manusia yang memiliki keyakinan bahwa saya yang paling tahu tentang diri saya sediri, dilawan dengan pernyataan bahwa algoritma eksternal dapat mengenalku lebih baik secara teoritis daripada saya sendiri. Algoritma yang mengamati setiap sistem yang meliputi tubuh dan otakku mampu mengenal dengan tepat siapa diriku, apa yang saya rasakan dan inginkan.

Para Kapitalis ialah mereka para pemilik kepentingan yang memiliki modal uang maupun kekayaan material, digunakan untuk mendapat keuntungan. Masyarakat yang menjadi imbasnya ialah mereka yang belum siap menghadapi revolusi industri 4.0, seperti tidak memiliki teknologi canggih, bahkan awan dan asing terhadap teknologi itu. ${ }^{14}$

Pada zaman berhala teknologi yang baru bagi dunia modern, manusia melihat dirinya hebat. Segala-galanya berpusat pada diri sendiri. Orang melupakan Tuhan dan melupakan diri sendiri. Dirinyalah Tuhan (Homo Deus est). Sebaliknya dengan iman, pusatnya adalah Tuhan. ${ }^{15}$

Tuhan telah dibunuh. Inilah bahasa Nietzsche yang mengatakan bahwa dosa atau suci itu tidak ada; yang ada ialah apa yang dikerjakan dan tidak dikerjakan. Bagaimana manusia era revolusi industri 4.0 dapat mendefinisikan Tuhannya ketika teknologi telah merambah ke banyak inovasi dalam berbagai sudut kehidupan? Contoh: kesehatan dijamin, umur panjang makin bisa direalisasikan, pertumbuhan bayi semakin solid, pertolongan pertama akan jantung dan stroke dapat dipercepat. Konsep Tuhan pada zamanan ini ialah "Tuan rumah Surga", namun zaman ini banyak hal yang menawarkan kenyamanan, keindahan, kenikmatan, bagaikan "kenikmatan surgawi" walaupun hanya sementara saja. Pada kenyataannya manusia tidak

14 Bdk., Donatus SermadaKelen. "Revolusi Industri 4.0: Kapitalisme Neo-Liberal, Homo Deus dan Wacana Solusi," Seri Filsafat Teologi29,no. 28 (Oktober 2019): 82-88.

15 Bdk., Berthold AntonPareira. “Dimanakah Allah Mereka?,"Seri Filsafat Teologi29,no. 28 (Oktober 2019): 131-143. 
meninggalkan agamanya seperti pergi ke gereja setiap minggu, tetapi pikiran mereka pasti mengalami "gangguan" untuk dapat masuk kepada keintiman dan kekhusyukan bergaul dengan Tuhannya. ${ }^{16}$

Revolusi industri 4.0 menantang manusia untuk berefleksi tentang arti, kodrat, dan statusnya di hadapan Allah. Kemajuan industri, teknologi, dan inteligensi artifisial terlalu kuat menggoda manusia untuk memosisikan dirinya sama seperti Allah, menyebut dirinya Allah dan bahkan mau melebihi Allah.

Revolusi industri 4.0 tidak hanya sedang mengubah apa yang kita buat tetapi juga mengubah siapa kita. Ia mengubah pemahaman manusia tentang kodratnya sebagai individu maupun mahluk sosial dan sebagai mahluk tercipta maupun sebagai mahluk yang memiliki daya cipta. Tidak lama lagi manusia akan menjadi "pembuat" atau "perancang" bayi-bayi manusia juga. Harari memprediksi dengan menggunakan teknologi modern dan AI, para pakar bioteknik, rekayasa genetik (genetic engineering) bisa menciptakan manusia Tuhan satu model manusia yang lebih superior, lebih tinggi kualitasnya daripada kualitas manusia sekarang. Namun disayangkan, meskipun memiliki kapasitas mental dan fisik yang sangat baik, kelemahannya adalah bahwa ia tidak memiliki daya untuk berpikir sendiri atau berefleksi, tidak memiliki kehendak, tidak memiliki emosi-emosi manusiawi, dan tidak memiliki rasa empati dan rasa belaskasihan.

Tidak luput bahwa dibalik revolusi industri 4.0 para pemilik kepentingan memiliki dasar dan motivasi yakni untuk memperoleh semakin banyak keuntungan finansial, harta kekayaan, dan kuasa. Pertanyaan "Cur Homo Deus" mengundang manusia yang amnesia akan Allah untuk dicabik-cabik pakaian cinta narsistiknya, berlaku rendah hati dan bijaksana di hadapan Allah dan manusia. ${ }^{17}$

\section{Terang Iman Menerangi Kebenaran di Era Revolusi Industri $\mathbf{4 . 0}$}

Seperti dikatakan Paus Fransiskus dalam ensikliknya, Kebenaran pada zaman ini adalah kebenaran teknologi, yang diukur dengan keterampilan ilmiah, yang berjalan dan menjadikan hidup manusia lebih mudah dan menyenangkan, kebenaran yang pasti, dapat dibagikan, kebenaran subjektif dan bukan untuk kebaikan bersama. ${ }^{18}$ Akibatnya manusia terjerumus ke dalam prinsip gnostisisme dan pelagianisme. ${ }^{19}$

16 Bdk., ArmadaRiyanto."Percikan Revolusi 4.0 Refleksi Filosofis Tentang Siapa Manusia dan Allah?,"Seri Filsafat Teologi29,no. 28 (Oktober 2019): 1-25.

17 Bdk., Kristoforus Bala, “Cur Homo Deus?,"Seri Filsafat Teologi29,no. 28 (Oktober 2019):230254.

18 Lumen Fidei, art. 25.

19 Bdk.,Fransiskus, Seruan Apostolik Gaudete et Exultate, Penterj. R.P. T. Krispurwana Cahyadi (Jakarta: Dokpen KWI, 2018), art. 36-62. 
Era revolusi industri 4.0 menawarkan kebenaran yang semu, dimana manusia hanya berhadapan dengan kepentingan, kepuasan dirinya tanpa mementingkan prinsip kebenaran yang baik untuk semua pihak. Kebenaran semu ini membuat akal budi manusia menjadi tergantikan oleh algoritma dan prinsip-prinsip yang individualistis. Manusia telah tergantikan oleh mesin, bahkan eksistensinya sebagai manusia telah diprogram oleh mesin algoritma yang "lebih canggih" dari manusia. Jika ditanya apa eksistensinya di dunia ini, maka jawabannya ialah tanyakan saja pada mesin algoritma.

Terjadinya perubahan yang revolusioner di era Industri 4.0 ini membuat manusia kehilangan konsep-konsep akan dirinya yang digantikan dengan konsep manusia sebagai makhluk badaniah belaka oleh ilmuan kontemporer yang materialis-positivistik. Manusia telah menjadi tuhan(Homo Deus Est) yang merasa bisa mengerti masa depan yang akan mereka hadapi, di lain pihak, mereka malah menjadi alat pembaruan data yang telah di atur oleh para pemilik kepentingan lewat algoritma yang ada.

Manusia di era revolusi industri 4.0 membutuhkan terang iman yang menuntun mereka berjalan di era kebenaran-kebenaran semu ini. Terang iman adalah cahaya yang menuntun manusia untuk berjalan dalam kegelapan. Pengetahuan, kecanggihan, kehebatan diri, kebenaran semu memang juga merupakan terang namun pada akhirnya mereka akan redup dan kalah dengan terang sejati ini. Pada saat terang-terang semu ini redup, maka tujuan hidup manusia yang selama ini digantungkan pada terang semu itu menjadi hilang. Manusia menjadi hidup tanpa arah dan tanpa tujuan. Manusia di era ini hendaknya berpegang erat pada terang sejati itu yang tidak akan pernah meredup karena berasal dari Allah sendiri.

Bagaimana terang iman dapat menuntun manusia untuk mencapai kebenaran sejati? Pengetahuan akan kebenaran memang penting untuk iman, tetapi percaya adalah modal awal untuk mengerti (bdk. Yes: 7:9). Dalam teks Kitab Suci, nabi mengatakan bahwa jikalau kamu tidak percaya, kamu tidak teguh jaya. Dalam versi bahasa Yunani dari Kitab Suci, "teguh jaya" diterjemahkan sebagai "mengerti". Begitu pula Santo Agustinus menyatakan hal yang senada. Dalam Pengakuannya, ia menyatakan tentang "pengertian" dan "menjadi teguh" sebagai kebenaran yang bisa diandalkan agar manusia beriman bisa berdiri teguh. ${ }^{20}$

Lalu, apakah jenis pengetahuan yang tercakup dalam iman? Salah satunya adalah pengetahuan tentang kasih. Seperti yang Santo Paulus nyatakan, "Dengan hati orang percaya" (Rom 10:10). Hati adalah inti dari pribadi manusia, dimana segala dimensi diri kita yang berbeda terikat satu sama lain.. Santo Gregorius Agung telah menuliskan bahwa kasih adalah suatu pengetahuan yang memiliki logikanya sendiri (amor ipse notitia est). ${ }^{21}$

20 Lumen Fidei, art. 23. 
Kasih memberikan sentuhan "pengertian" pada kebenaran yang kita cari, kebenaran yang dapat memberi makna pada perjalanan hidup kita. ${ }^{22}$ Pengertian iman dapat lahir ketika kita mampu menerima kasih Allah yang mengubah dari dalam dan memampukan kita untuk memandang dengan kacamata yang baru, sebab kasih itu sendiri membawa pencerahan. ${ }^{23}$ Tentu kasih dapat menjelaskan bahwa terang iman dapat menjadi jawaban bagi masyarakat Revolusi Indsutri 4.0. yang mengalami krisis terhadap arti, kodrat, dan statusnya sebagai manusia karena hanya memberikan makna artifisial pada hidup mereka.

Para "tuhan" 24 hendaknya menundukkan dirinya agar menyadari jalan kebenaran semu yang mereka tempuh. Percaya adalah modal awal untuk mencapai kebenaran sejati. Mengandalkan percaya saja pada Sang Kebenaran sejati, maka Ia akan memberikan cahaya/ terang iman yang tidak akan meredup dan membimbing untuk menghindarkan diri dari kebenarankebenaran semu. Dengan dituntun oleh terang iman kepada kebenaran, manusia di era revolusi industri 4.0 ini akan menyadari bahwa pencariannya akan kebenaran bukanlah berpuncak pada revolusi industri 4.0. Mereka masih berada dalam perjalanan ditengah terang-terang semu. Terang-terang teknologi, algoritma, dan sebagainya akan kalah dengan terang iman yang menuntun mereka pada Sang Kebenaran sejati. Jika kamu tidak percaya, kamu tidak akan mengerti dan teguh jaya! ${ }^{25}$

\section{Kesimpulan}

Kebenaran-kebenaran semu di era revolusi industri 4.0 ini membuat manusia merasa menemukan kebenaran sejati yang nyatanya memalingkan mereka pada tujuan sejati yakni sang Kebenaran, akibat para pemilik kepentingan yang mengaktualisasikan pemikiran ini lewat algoritma-algoritma demi keuntungan mereka sendiri. Manusia dalam posisi ini adalah korban, mereka menjadi buta akan Sang Kebenaran sejati.

Hal yang dibutuhkan manusia di jaman ini ialah Terang Iman, yang dipancarkan dari Sang Kebenaran sejati. Yang diperlukan manusia saat ini ialah mempercayakan diri pada tuntunan dari terang Iman itu. Terang iman membawa manusia untuk menuju Sang Kebenaran sejati, dibanding terangterang semu yang akan meredup dan membuat manusia kehilangan akan tujuan dan arah hidupnya.

21 Ibid, art. 27.

22 Ibid.

23 Ibid.

24 Kata tuhan merujuk pada istilah "Homo Deus est" yang berarti kedudukan manusia yang karena kehebatannya hendak menyerupai Tuhannya.

25 Ibid, art. 23. 
Pertanyaan mendasar yang mungkin menjadi penelitian selanjutnya ialah apakah Terang Iman yang menuntun manusia menuju Kebenaran sejati itu, hanya diperoleh dari keputusan manusia untuk beragama?

\section{Daftar Pustaka}

\section{Sumber Buku}

Riyanto, Armada. “Metafisika."Diktat, STFT Widya Sasana, 2002.

\section{Dokumen Gereja}

Fransiskus. Ensiklik Lumen Fidei Terang Iman. Penterj. R.P. T. Krispurwana Cahyadi. Jakarta: Dokpen KWI, 2014.

Fransiskus. Seruan Apostolik Gaudete et Exultate. Penterj. R.P. T. Krispurwana Cahyadi. Jakarta: Dokpen KWI, 2018.

\section{Sumber Internet}

https://kbbi.wveb.id/iman, diakses tanggal 18 Desember 2020.

\section{Sumber Jurnal}

Bala, Kristoforus. “Cur Homo Deus?." Seri Filsafat Teologi29,no. 28 (Oktober 2019):230-254.

Kelen, Donatus Sermada. "Revolusi Industri 4.0: Kapitalisme Neo-Liberal, Homo Deus dan Wacana Solusi." Seri Filsafat Teologi29,no. 28 (Oktober 2019): 82-88.

Pareira, Berthold Anton. "Dimanakah Allah Mereka?." Seri Filsafat Teologi29,no. 28 (Oktober 2019): 131-143.

Riyanto, Armada."Percikan Revolusi 4.0 Refleksi Filosofis Tentang Siapa Manusia dan Allah?." Seri Filsafat Teologi29,no. 28 (Oktober 2019): 1-25.

Valentinus. "Antara EUREKA dan ERICA: Konsep Manusia di Era 4.0." Seri Filsafat Teologi29, no. 28 (Oktober 2019): 64-73. 